\title{
Purification and Properties of Glutamine Synthetase from Methylococcus capsulatus (Bath)
}

\author{
By J. COLIN MURRELL† AND HOWARD DALTON* \\ Department of Biological Sciences, University of Warwick, Coventry CV4 7AL, U.K.
}

(Received 5 July 1982; revised 13 October 1982)

\begin{abstract}
The obligate methanotroph Methylococcus capsulatus (Bath) was grown in batch and continuous culture with ammonia, nitrate or dinitrogen as the sole nitrogen source. Cell-free extracts from these cultures all contained the ammonia assimilation enzyme glutamine synthetase. During growth on ammonia, however, the glutamine synthetase was biosynthetically inactive. Isolation of glutamine synthetase from $M$. capsulatus (Bath) resulted in a 133-fold purification with a yield of $11 \%$. The purified enzyme had a molecular weight of 617000 and a subunit size of 60000 Dal. The metal ion and nucleotide specificity of glutamine synthetase was studied using both a biosynthetic assay and an artificial assay - the $\gamma$-glutamyltransferase assay. Feedback inhibition by several end-products of glutamine metabolism was observed and their effects were cumulative. Control of glutamine synthetase activity by adenylylation/deadenylylation was demonstrated by snake venom phosphodiesterase treatment of the enzyme isolated from cells grown with different nitrogen sources.
\end{abstract}

\section{INTRODUCTION}

Methylococcus capsulatus (Bath) is an obligate methanotroph which utilizes methane as its sole source of carbon and energy. It grows with ammonia or nitrate as nitrogen sources and can also fix dinitrogen $\left(\mathrm{N}_{2}\right)$ at reduced oxygen tensions. Both nitrate and dinitrogen are reduced to ammonia which is then assimilated into the cell via glutamine synthetase.

The most extensive studies on the enzyme glutamine synthetase (GS) have been carried out in Escherichia coli [reviewed by Ginsburg \& Stadtman (1973) and Tempest et al. (1973)]. They established that GS in $E$. coli would respond to changes in extracellular concentrations of ammonia. When the ammonia concentration was high, GS rapidly lost its ability to form glutamine in the biosynthetic reaction:

$$
\text { L-glutamate }+\mathrm{NH}_{3}+\mathrm{ATP} \stackrel{\mathrm{Mg}^{2+}}{\rightarrow} \text { L-glutamine }+\mathrm{ADP}+\mathrm{Pi}
$$

although the enzyme still retained $\gamma$-glutamyltransferase activity in the artificial assay:

$$
\text { L-glutamine }+\mathrm{NH}_{2} \mathrm{OH} \underset{\mathrm{Mn}^{2+} \text { or } \mathrm{Mg}^{2+}}{\stackrel{\text { ADP, Arsenate }}{\longrightarrow}} \gamma \text {-glutamyl hydroxamate }+\mathrm{NH}_{3}
$$

The ability of GS to form glutamine in the biosynthetic reaction was rapidly decreased by the attachment of adenylyl groups to the enzyme. Removal of these adenylyl groups resulted in restoration of biosynthetic activity observed during growth in medium containing low concentrations of ammonia. The reader is referred to the reviews by Tyler (1978) and Dalton (1979) for a detailed description of the adenylylation/deadenylylation cascade mechanism found in E. coli and many other organisms including Klebsiella aerogenes (Bender et al., 1977),

† Present address: Department of Microbiology and Immunology, University of Washington, Seattle, Washington 98195, U.S.A.

Abbreviations: GS, glutamine synthetase; SVP, snake venom phosphodiesterase. 
Azotobacter vinelandii (Siedel \& Shelton, 1979) and Rhodopseudomonas capsulata (Johansson \& Gest, 1977).

A second means of GS regulation is cumulative feedback inhibition by the end-products of glutamine metabolism, first observed in E. coli by Woolfolk \& Stadtman (1964) and subsequently found to occur in several other organisms including Pseudomonas fluorescens, Salmonella typhimurium and Clostridium pasteurianum (Hubbard \& Stadtman, 1967a) and $A$. vinelandii (Kleinschmidt \& Kleiner, 1978). In organisms for which there is no evidence for control of GS by adenylylation, it is thought that feedback inhibition is the main mechanism by which GS activity is regulated, e.g. as in Bacillus subtilis (Deuel \& Stadtman, 1970), Bacillus stearothermophilus (Wedler et al., 1976) and Anabaena CA (Stacey et al., 1979).

Although the presence of GS has been reported in several methanotrophs (Shishkina \& Trotsenko, 1979; Bailey et al., 1978) very little was known about the properties and regulation of this enzyme in these organisms. This paper describes the purification and properties of GS from $M$. capsulatus (Bath). The effects of metal ions in both the GS biosynthetic and $\gamma$-glutamyltransferase assays are reported and the control of enzyme activity by feedback inhibition and covalent modification are discussed.

\section{METHODS}

Growth of organism and preparation of cell-free extracts. Methylococcus capsulatus (Bath) (Whittenbury et al., 1970) was grown in continuous culture in a 2.51 fermenter (L. H. Engineering, Stoke Poges, Bucks., U.K.) on mineral salts (MS) medium (Dalton \& Whittenbury, 1976) supplemented with $1 \mathrm{~g}$ potassium nitrate $1^{-1}$ (NMS medium) or $1 \mathrm{~g}$ ammonium chloride $1^{-1}$ (AMS medium). The chemostat was operated under oxygen limitation with methane $\left[20 \%(\mathrm{v} / \mathrm{v})\right.$ in air at a flow rate of $\left.50 \mathrm{ml} \mathrm{min}^{-1}\right]$ as carbon source. Temperature and $\mathrm{pH}$ were maintained at $45^{\circ} \mathrm{C}$ and 6.8 , respectively. A dilution rate $(D)$ of $0.05 \mathrm{~h}^{-1}$ was used and at steady-state the dry weight of the culture was $1.0-1.5 \mathrm{mg} \mathrm{ml}^{-1}$, depending on the nitrogen source and on the growth medium.

At steady-state, bacteria were harvested by centrifugation for $10 \mathrm{~min}$ at $20000 \mathrm{~g}\left(4^{\circ} \mathrm{C}\right)$. After washing once with ice-cold $25 \mathrm{~mm}$-imidazole/ $\mathrm{HCl}$ buffer $\mathrm{pH} 7 \cdot 15$ (buffer A), the cells were resuspended in $25 \mathrm{~mm}$-imidazole/ $\mathrm{HCl}$ buffer pH 7.15, containing $5 \mathrm{~mm}$-magnesium chloride, $10 \mathrm{~mm}$-sodium glutamate, $5 \mathrm{~mm}$-2-mercaptoethanol and 1 mM-EDTA (buffer B). Cell extracts were prepared by two passages of the cell suspension through a pre-cooled French pressure cell at $137 \mathrm{MPa}$, followed by centrifugation at $38000 \mathrm{~g}$ for $30 \mathrm{~min}$. The resulting clear red supernate was decanted off and this soluble extract was immediately frozen in pellet form by drop-wise addition into vials standing in liquid nitrogen. These pellets were stored at $-80^{\circ} \mathrm{C}$.

Large quantities of whole cells of $M$. capsulatus (Bath) for preparation of cell extracts for enzyme purification were grown at $45^{\circ} \mathrm{C}$ in batch cultures on MS, NMS or AMS medium in a 1001 fermenter (L. H. Engineering). The fermenter was inoculated with 101 of a continuous culture overflow. After $18-24 \mathrm{~h}$, when the cell density had reached approximately $2 \mathrm{mg} \mathrm{ml}^{-1}$, the culture was harvested using a Westfalia continuous centrifuge (Westfalia Separator, Wolverton, Bucks., U.K.). Cell-free extracts were then prepared as described above.

Enzyme assays. Glutamine synthetase (GS) [EC 6.3.1.2; L-glutamate : ammonia ligase (ADP-forming)] was assayed using two assay systems.

(1) GS $\gamma$-glutamyltransferase activity was assayed by the method of Bender et al. (1977). The concentrations of reactants in this assay mixture (total volume $0.5 \mathrm{ml}$ ) were: imidazole $/ \mathrm{HCl}$ buffer $\mathrm{pH} 7 \cdot 15,135 \mathrm{~mm}$; manganese chloride, $0.27 \mathrm{~mm}$; potassium arsenate, $25 \mathrm{~mm}$; sodium-ADP, $0.36 \mathrm{~mm}$; and cell extract. Any inhibitors etc. were added to the reaction mixture prior to initiation of the reaction with L-glutamine (final concentration $20 \mathrm{~mm}$ ). After $10 \mathrm{~min}$ the reaction was terminated by the addition of $1.0 \mathrm{ml}$ 'stopmix' containing $55 \mathrm{~g}$ ferric chloride, $20 \mathrm{~g}$ TCA and $21 \mathrm{ml}$ concentrated $\mathrm{HCl}(1 \text { water })^{-1}$. Samples were then centrifuged to remove any precipitate before the $A_{540}$ was measured. A standard curve for $\gamma$-glutamyl hydroxamate was prepared using commercial $\gamma$-glutamyl hydroxamate. ( $1 \mu \mathrm{mol} \gamma$-glutamyl hydroxamate gave an $A_{540}$ of 0.63 ).

(2) GS biosynthetic activity in cell extracts was assayed by a method similar to that used by Woolfolk et al. (1966). The concentrations of reactants in the assay mixture were: imidazole/HCl buffer $\mathrm{pH} 7 \cdot 15,50 \mathrm{~mm}$; sodium glutamate, $100 \mathrm{~mm}$; ammonium chloride, $50 \mathrm{~mm}$ and magnesium chloride $50 \mathrm{~mm}$. The total assay volume including enzyme was $0.5 \mathrm{ml}$. Any inhibitors etc. were added to the reaction mixture prior to initiation of the reaction with ATP ( $1 \mathrm{mM}$ final concentration). After $10 \mathrm{~min}$, the reaction was terminated by the addition of $1.0 \mathrm{ml}$ $10 \%(\mathrm{w} / \mathrm{v})$ TCA. Samples were then centrifuged to remove any precipitate, and the inorganic phosphate released from ATP was measured by the method of Baginski et al. (1967). All enzyme assays were done at $45^{\circ} \mathrm{C}$ and enzyme activities are given as nmol product $\min ^{-1}$ (mg protein) ${ }^{-1}$.

Purification of GS. All procedures were carried out at $4{ }^{\circ} \mathrm{C}$. Elution of protein from columns was monitored at $206 \mathrm{~nm}$ by a Uvicord S UV monitor (LKB). Step $1: 100 \mathrm{ml}$ of crude, soluble cell-free extract was applied to a column $(4 \times 30 \mathrm{~cm})$ of DEAE-cellulose, previously equilibrated with buffer $B$. The column was eluted with a 0 to 
1.2 $\mathrm{M}$-sodium chloride gradient at a flow rate of $100 \mathrm{ml} \mathrm{h}^{-1}$. Fractions $(5 \mathrm{ml})$ were collected and those showing significant GS activity were pooled and dialysed to remove sodium chloride. The pooled fractions were then concentrated by ultramembrane filtration to give a final volume of $5 \mathrm{ml}$. Step 2: GS protein from the DEAEcellulose chromatography step was applied to a column $(3 \times 100 \mathrm{~cm})$ of Sepharose $4 \mathrm{~B}$, previously equilibrated with buffer $B$. The column was eluted with the same buffer at a flow rate of $20 \mathrm{ml} \mathrm{h}^{-1}$. GS-active fractions were pooled. Step 3: pooled fractions from step 2 were applied to a column $(4 \times 20 \mathrm{~cm})$ of DEAE-Sephacel, previously equilibrated with buffer B. The column was eluted with a 0 to $0.5 \mathrm{M}$-sodium chloride gradient at a flow rate of $50 \mathrm{ml} \mathrm{h}^{-1}$. Active fractions were pooled and dialysed to remove sodium chloride. Pooled fractions were concentrated, as in step 1, to a volume of $2 \mathrm{ml}$. Step 4 : pooled fractions from step 3 were applied to a column $(1 \times$ $30 \mathrm{~cm}$ ) of Sephacryl S-300, previously equilibrated with buffer B. The column was eluted with the same buffer at a flow rate of $5 \mathrm{ml} \mathrm{h}^{-1}$, and $1 \mathrm{ml}$ fractions were collected. GS-active fractions were pooled and frozen by drop-wise addition into vials standing in liquid nitrogen. The resultant pellets were stored at $-80{ }^{\circ} \mathrm{C}$.

$P A G E$. The procedure of O'Farrell (1975) was followed for the preparation and running of $18 \times 15 \times 0 \cdot 15 \mathrm{~cm}$ slab polyacrylamide gels. The discontinuous buffer system of Laemmli (1970) was used. The molecular weight of the GS subunit was estimated by SDS-PAGE. The stacking gel, resolving gel and running buffer contained SDS at $0.1 \%(\mathrm{w} / \mathrm{v})$ and 2-mercaptoethanol at $10 \mathrm{mM}$. Enzyme purity was assessed with non-denaturing tube polyacrylamide gels (Gabriel, 1971), using the buffer system described above, by staining the Coomassie blue. GS was located in unstained tube gels by the method of Kleinschmidt \& Kleiner (1978).

Molecular weight determinations. The molecular weight of GS was determined by gel filtration on a column of Sepharose $4 \mathrm{~B}$, equilibrated at $4{ }^{\circ} \mathrm{C}$ with buffer $\mathrm{B}$ and run at a flow rate of $20 \mathrm{ml} \mathrm{h}^{-1}$. Rabbit muscle phosphorylase kinase (1300000), E. coli $\beta$-galactosidase (540000), jack bean urease (480000), horse spleen apoferritin (443000), bovine liver catalase (232000) and rabbit muscle aldolase (160000) were used as molecular weight standards.

The subunit size of GS was determined by SDS-PAGE using the molecular weight markers rabbit muscle phosphorylase b (94000), BSA (67000), ovalbumin (43000), soybean trypsin inhibitor (20100) and bovine $\alpha$ lactalbumin (14400). Relative mobilities were measured with respect to bromophenol blue.

Snake venom phosphodiesterase (SVP) treatment of $G S$. The reaction was carried out in $100 \mathrm{~mm}$ Tris/ $\mathrm{HCl}$ buffer $\mathrm{pH} 7 \cdot 8$, containing $20 \mathrm{mg}$ of purified enzyme and $20 \mathrm{mg} \mathrm{SVP}$. After $1 \mathrm{~h}$ incubation at $37^{\circ} \mathrm{C}$, the reaction was terminated by the addition of $1 \mathrm{ml} \mathrm{10 \%}$ TCA and precipitated proteins were removed by centrifugation. AMP was identified by TLC using polyethyleneimine cellulose and nucleotide monophosphate standards (Randerath \& Randerath, 1967). The solvent used for ascending elution was $1 \mathrm{M}$-acetic acid.

\section{RESULTS AND DISCUSSION}

\section{Purification of GS from $M$. capsulatus (Bath)}

It is not possible to purify GS by affinity chromatography using the affinity ligand Cibacron blue covalently linked to agarose, and so a conventional purification procedure was adopted, the protocol for which is shown in Table 1 and described in Methods. The cell-free extract was prepared from approximately $25 \mathrm{~g}$ dry wt cells from a $100 \mathrm{l}$ batch culture of $M$. capsulatus (Bath) grown on NMS medium. The purification procedure gave an $11 \%$ yield with an overall 133 -fold purification of the enzyme (Table 1). The enzyme was judged to be better than $95 \%$ pure following electrophoresis in polyacrylamide gels under denaturing and non-denaturing conditions. Therefore, GS constituted about $0.7 \%(\mathrm{w} / \mathrm{w})$ of the total soluble protein in the cell extract.

Enzyme eluted from DEAE-cellulose, Sepharose 4B, DEAE-Sephacel and Sephacryl S-300 as a single peak of activity when measured by both the $\gamma$-glutamyltransferase assay and the GS biosynthetic assay, indicating, on the basis of both charge and size, the presence of only one form of GS in $M$. capsulatus (Bath).

In the presence of buffer $\mathrm{B}$, containing the stabilizing ligands EDTA, glutamate, 2mercaptoethanol and $\mathrm{Mg}^{2+}$, pure GS was completely stable for several months at $-80^{\circ} \mathrm{C}$ and could also be stored at $4{ }^{\circ} \mathrm{C}$ for several hours with almost no loss of activity. The stabilizing effects of these ligands is similar to that found with GS from Anabaena cylindrica (Sampaio et al., 1979).

\section{Molecular weight and subunit of $G S$}

The molecular weight of GS was estimated by gel filtration to be 617000 (Fig. 1). This is comparable with molecular weights of GS from several bacteria including A. cylindrica, E. coli, $A$. vinelandii and Bacillus species. However, the subunit molecular weight of GS from $M$. 
Table 1. Purification protocol for GS from M. capsulatus (Bath)

\begin{tabular}{|c|c|c|c|c|c|}
\hline Step & $\begin{array}{l}\text { Total protein } \\
(\mathrm{mg})\end{array}$ & $\begin{array}{l}\text { Total activity } \\
\quad \text { (units)* }\end{array}$ & $\begin{array}{c}\text { Specific activity } \\
\left.[\text { units (mg protcin) })^{-1}\right]^{*}\end{array}$ & $\begin{array}{l}\text { Yield } \\
(\%)\end{array}$ & $\begin{array}{l}\text { Purification } \\
\text { factor }\end{array}$ \\
\hline Crude extract & $5000)$ & 11500 & $2 \cdot 3$ & 100 & 1 \\
\hline $\begin{array}{l}\text { DEAF-cellulose } \\
\text { cluate }\end{array}$ & 619 & 6871 & 11.1 & 60 & 5 \\
\hline $\begin{array}{l}\text { Sephatrose 4B } \\
\text { cluate }\end{array}$ & 101 & 4848 & $48 \cdot 0$ & 42 & 21 \\
\hline $\begin{array}{l}\text { DFAF-Sephacel } \\
\text { eluate }\end{array}$ & 25 & 1770 & $70 \cdot 8$ & 15 & 31 \\
\hline $\begin{array}{l}\text { Sephacryl S-300) } \\
\text { cluate }\end{array}$ & 4 & 1224 & $306 \cdot 0$ & 11 & 133 \\
\hline
\end{tabular}

* One enzyme unit $=1 \mu \mathrm{mol} \gamma$-glutamyl hydroxamate produced $\min ^{-1}$.

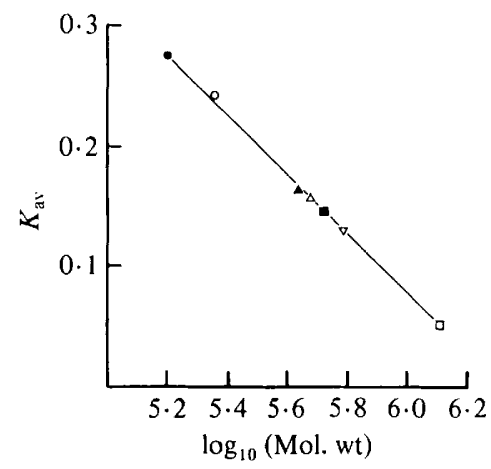

Fig. 1. Molecular weight estimation of GS on a Sepharose $4 \mathrm{~B}$ column. The $K_{\mathrm{av}}$ values were calculated from $K_{\mathrm{av}}=\left(V_{\mathrm{e}}-V_{\mathrm{o}}\right)\left(V_{\mathrm{t}}-V_{\mathrm{o}}\right)$ where $V_{\mathrm{e}}$ is the elution volume, $V_{\mathrm{o}}$ the void colume and $V_{\mathrm{t}}$ the bed volume. The standards used were : aldolase $(\bigcirc)$, catalase $(O)$, ferritin $(\boldsymbol{\Delta})$, urease $(\triangle)$, $\beta$-galactosidase ( $\square$ ) and phosphorylase kinase ( $\square$ ). See Methods for details.

capsulatus (Bath) of 60000 as estimated using SDS-PAGE (Fig. 2) is considerably higher than values reported for GS enzymes from other organisms and suggested a decameric structure for the enzyme.

\section{Properties of $G S$}

The $\mathrm{pH}$ optimum for GS activity measured by both the $\gamma$-glutamyltransferase assay and the GS biosynthetic assay was found to be $\mathrm{pH} 7 \cdot 15$. The optimum temperature for activity was $45^{\circ} \mathrm{C}$, the growth temperature of the organism. All subsequent assays were done under these optimum conditions.

$K_{\mathrm{m}}$ values of substrates of GS in both the GS biosynthetic assay and $\gamma$-glutamyltransferase assay were determined using purified enzyme from nitrate-grown $M$. capsulatus (Bath) (Table 2 ). The $K_{\mathrm{m}}$ for hydroxylamine was estimated to be $14.0 \mathrm{~mm}$ which is considerably higher than the $K_{\mathrm{m}}$ value of $0.3 \mathrm{~mm}$ reported by Bailey et al. (1978) for the GS from Methylococcus NCIB 11803. The $K_{\mathrm{m}}$ value for ammonia was low and is in agreement with values obtained for GS enzymes of many other prokaryotes. The high affinity of GS from $M$. capsulatus (Bath) provides good evidence for ammonia assimilation by this enzyme during growth conditions in which the extracellular concentration of ammonia is low. $K_{\mathrm{m}}$ values for glutamate, ATP, glutamine and ADP confirmed that concentrations of these reactants used routinely in GS assays were in excess and not rate-limiting.

\section{Nucleotide specificity}

The nucleotide specificity of GS was investigated using cell extracts of $M$. capsulatus (Bath) grown on nitrate-supplemented medium (Table 3). The enzyme showed a marked dependence 


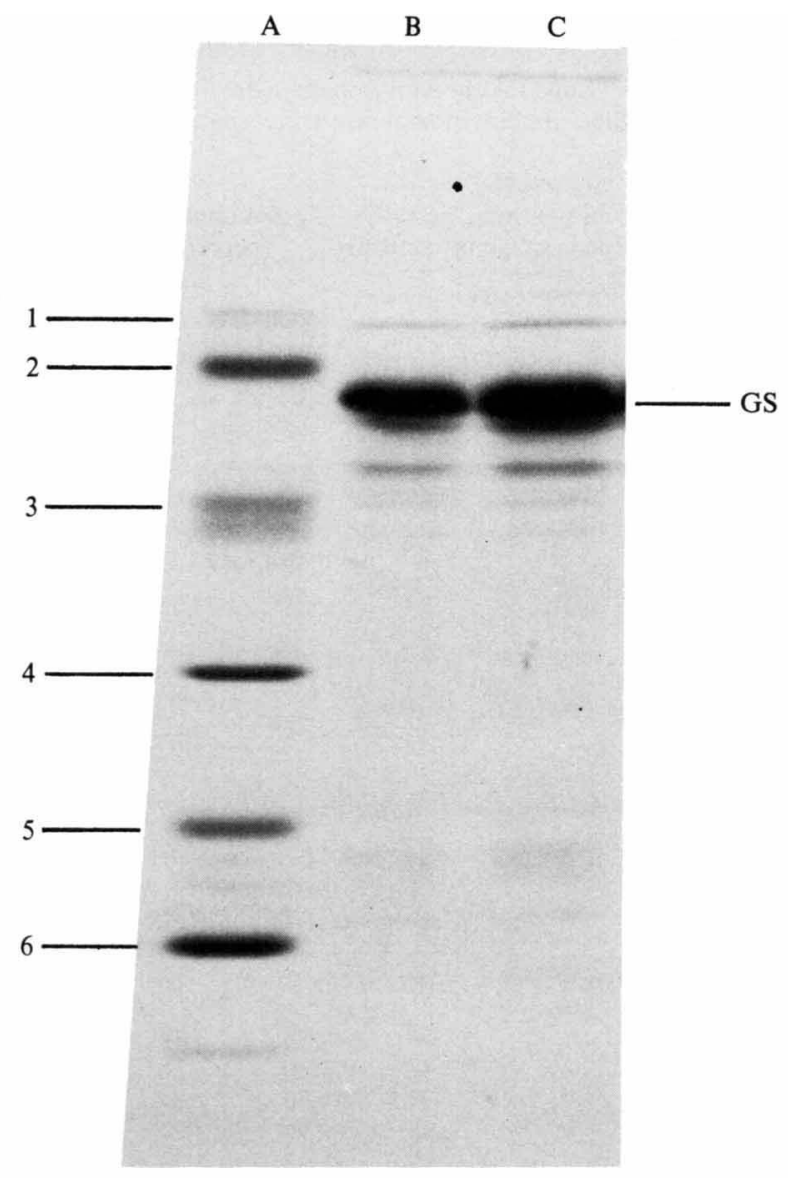

Fig. 2. SDS-PAGE of GS and molecular weight standards on a $5 \%$ to $30 \%(\mathrm{w} / \mathrm{v})$ polyacrylamide gradient gel (see Methods for details). The standards used were: (1) phosphorylase b $(94000) ;(2)$ BSA $(67000)$; (3) ovalbumin $(43000)$; (4) carbonic anhydrase $(30000)$; (5) trypsin inhibitor $(20000) ;(6) x-$ lactalbumin (14400). Track A, standards $(100 \mu \mathrm{g}$ protein); track B, GS (50 $\mu \mathrm{g}$ protein); track C, GS $(100 \mu \mathrm{g}$ protein).

\section{Table 2. $K_{\mathrm{m}}$ values for substrates of $G S$}

The $K_{\mathrm{m}}$ values were determined using an excess of all substrates other than the substrate in question. Initial velocities were measured and $K_{\mathrm{m}}$ values determined from Lineweaver-Burk plots. Linear regression analysis of plots gave correlation coefficients greater than 0.987 in all cases.

Assay

$\gamma$-Glutamyltransferase assay

Biosynthetic assay
Substrate

Hydroxylamine

Glutamine

ADP

Ammonia

Glutamate

ATP
$K_{\mathrm{m}}(\mathrm{mM})$

$14 \cdot 00$

4.87

$0 \cdot 15$

0.72

$2 \cdot 25$

$0 \cdot 60$

for ATP in the biosynthetic assay although other nucleotide triphosphates, particularly GTP, could substitute for ATP to varying extents. These effects have also been noted with GS enzymes from many other bacteria including $E$. coli (Woolfolk et al., 1966), B. stearothermophilus (Wedler \& Hoffmann, 1974) and Rhodopseudomonas palustris (Alef et al., 1981). GS from M. capsulatus 
Table 3. Nucleotide specificity of $G S$

\begin{tabular}{|c|c|c|}
\hline Nucleotide & $\begin{array}{c}\text { GS } \\
\text { biosynthetic activity } \\
\text { (percentage of control) }\end{array}$ & $\begin{array}{c}\text { GS } \\
\gamma \text {-glutamyltransferase activity } \\
\text { (percentage of control) }\end{array}$ \\
\hline ATP & 100 & 14 \\
\hline GTP & 59 & 11 \\
\hline ITP & 32 & 12 \\
\hline TTP & 10 & 12 \\
\hline UTP & 10 & 9 \\
\hline СТP & 0 & 11 \\
\hline ADP & 0 & 100 \\
\hline GDP & 0 & 67 \\
\hline IDP & 0 & 41 \\
\hline TDP & 0 & 34 \\
\hline UDP & 0 & 27 \\
\hline CDP & 0 & 24 \\
\hline AMP & 0 & 19 \\
\hline None & 0 & 0 \\
\hline
\end{tabular}

Table 4. Feedback inhibition of GS activity

GS

biosynthetic activity (percentage of control)*

Inhibitor

L-Alanine

L-Glutamine

Glycine

L-Histidine

L-Serine

L-Tryptophan

Glucosamine 6-phosphate

AMP

Carbamyl phosphate
Inhibitor concn (mM)

$\begin{array}{ccr}1 & 5 & 10 \\ 64 & 28 & 14 \\ 48 & 10 & 6 \\ 93 & 70 & 34 \\ 98 & 94 & 89 \\ 89 & 33 & 24 \\ 98 & 98 & 97 \\ 94 & 83 & 78 \\ 84 & 57 & 38 \\ \text { ND } & \text { ND } & 49\end{array}$

GS

$\gamma$-glutamyltransferase activity (percentage of control) $\dagger$

$\begin{array}{rcr}1 & 5 & 10 \\ 48 & 20 & 10 \\ \text { ND } & \text { ND } & \text { ND } \\ 83 & 47 & 35 \\ 100 & 99 & 76 \\ 85 & 82 & 62 \\ 99 & 96 & 95 \\ 100 & 98 & 92 \\ 90 & 75 & 62 \\ 100 & 92 & 75\end{array}$

ND, Not determined.

* Control GS biosynthetic activity $=97 \mathrm{nmol} \mathrm{m^{-1 }}(\mathrm{mg} \text { protein })^{-1}$.

$\dagger$ Control GS $\gamma$-glutamyltransferase activity $=9.4 \mu \mathrm{mol} \mathrm{min}^{-1}$ (mg protein $)^{-1}$.

(Bath), like the enzyme from E. coli (Woolfolk et al., 1966), showed maximum activity with ADP and good activity with GDP in the $\gamma$-glutamyltransferase assay.

\section{Feedback inhibition of $G S$}

The possibility of feedback regulation of GS by various amino acids and other potential endproducts of glutamine metabolism, e.g. glucosamine 6-phosphate, carbamyl phosphate and AMP was investigated using partially purified GS from nitrate-grown $M$. capsulatus (Bath) (Table 4).

When tested individually, several end-products of glutamine metabolism caused limited degrees of inhibition of GS activity. When two or more inhibitors were present in the assay, their effects were cumulative. This suggested that inhibitors were acting independently and that each may have occupied a separate binding site on the GS enzyme.

Feedback inhibition of GS by the above inhibitors has been reported in many bacteria including $R$. capsulata (Johansson \& Gest, 1976), K. aerogenes (Bender et al., 1977) and Bacillus licheniformis (Hubbard \& Stadtman, 1967b). In E. coli, the sensitivity of GS towards feedback inhibition was found to be altered by adenylylation (Kingdon \& Stadtman, 1967). The 
Table 5. Effects of feedback inhibitors on GS activity from dinitrogen- and ammonia-grown cells

The specific activities of GS in dinitrogen-grown (MS) and ammonia-grown (AMS) extracts prepared from cells grown to steady-state were 5.4 and $2.3 \mu \mathrm{mol} \mathrm{min}^{-1}$ (mg protein) ${ }^{-1}$, respectively.

\begin{tabular}{lcc} 
Inhibitor & \multicolumn{2}{c}{ Percentage of control activity } \\
\cline { 2 - 3 } No m $)$ & \multicolumn{1}{c}{ MStract } & AMS extract \\
None & 100 & 100 \\
L-Tryptophan & 94 & 77 \\
L-Histidine & 78 & 64 \\
AMP & 57 & 42 \\
CTP & 98 & 99
\end{tabular}

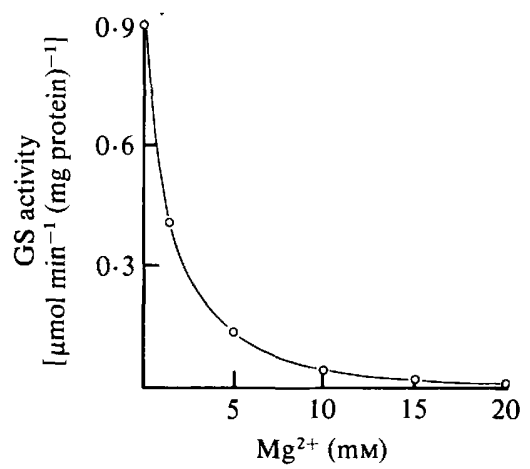

Fig. 3. Inhibition of GS activity by $\mathrm{Mg}^{2+}$ in the $\gamma$-glutamyltransferase assay.

adenylylated form of the enzyme, from cells grown in medium containing high extracellular levels of ammonia, was found to be more susceptible to feedback inhibition by L-histidine, $\mathrm{L}$ tryptophan, CTP and ATP than the deadenylylated form (from cells grown in the absence of ammonia), when assayed by the $\gamma$-glutamyltransferase assay. Therefore, GS enzymes in cell-free extracts of dinitrogen- and ammonia-grown $M$. capsulatus (Bath) were compared for inhibition by these metabolites in the transferase assay (Table 5). GS from ammonia-grown cells was inhibited by L-tryptophan, L-histidine and AMP to a higher degree than the GS from dinitrogengrown cells, suggesting that GS from ammonia-grown cells might have been adenylylated. In order to establish whether GS activity in $M$. capsulatus (Bath) was regulated by the system of adenylylation/deadenylylation observed in several Enterobacteriaceae, the effects of $\mathbf{M g}^{2+}$ and $\mathrm{Mn}^{2+}$ ions were studied.

\section{Effect of metal ions on GS activity}

In $E$. coli, GS has been shown to be affected by metal ions when the $\gamma$-glutamyltransferase assay was used to determine activity: $\mathrm{Mn}^{2+}$ ions supported activity of both adenylylated (biosynthetically inactive) and deadenylylated (biosynthetically active) enzyme although the $\mathrm{pH}$ optimum varied considerably with the state of adenylylation (Shapiro \& Stadtman, 1970). Furthermore, the addition of $\mathrm{Mg}^{2+}$ ions to the $\mathrm{Mn}^{2+}$-dependent transferase assay inhibited the activity of the adenylylated subunits only (Stadtman et al., 1970) and so the relative state of adenylylation can be measured by comparing the activity in the presence of $\mathrm{Mn}^{2+}$ ions with the activity in the presence of both $\mathrm{Mn}^{2+}$ and $\mathrm{Mg}^{2+}$ ions.

Activity of the enzyme from $M$. capsulatus (Bath) was completely dependent on $\mathrm{Mn}^{2+}$, showing a maximum activity at $0.3 \mathrm{~mm}-\mathrm{Mn}^{2+}$ in the assay mixture. No other divalent cation tested, including $\mathrm{Mg}^{2+}, \mathrm{Co}^{2+}, \mathrm{Ni}^{2+}, \mathrm{Ca}^{2+}, \mathrm{Fe}^{2+}, \mathrm{Zn}^{2+}$ and $\mathrm{Cu}^{2+}$ would support $\gamma$-glutamyltransferase activity. Of these divalent cations ( 5 or $10 \mathrm{mM}$ ), only $\mathrm{Mg}^{2+}$ showed any significant inhibition of $\mathrm{Mn}^{2+}$-supported transferase activity in nitrate-grown cells (Fig. 3). 
Table 6. Inhibition of $G S$ activity by $\mathrm{Mg}^{2+}$ in cell-free extracts of $M$. capsulatus (Bath)

Extracts were prepared from chemostat-grown cells grown with ammonia, nitrate or dinitrogen as the nitrogen source. All assays contained $\mathrm{Mn}^{2+}(0.27 \mathrm{mM})$ and $\gamma$-glutamyltransferase activity was measured as described in Methods.

\begin{tabular}{|c|c|c|c|c|c|c|c|}
\hline \multirow[b]{2}{*}{$\begin{array}{l}\text { Nitrogen source } \\
\text { for growth }\end{array}$} & \multirow[b]{2}{*}{$\begin{array}{l}\mathrm{MgCl}_{2} \\
\text { concn (mM) }\end{array}$} & \multicolumn{6}{|c|}{$\begin{array}{c}\text { GS } \gamma \text {-glutamyltransferase activity } \\
{\left[\mu \mathrm{mol} \mathrm{min}^{-1}(\mathrm{mg} \text { protein })^{-1}\right]}\end{array}$} \\
\hline & & 0 & 2 & 5 & 10 & 15 & 20 \\
\hline Ammonia & & $1 \cdot 10$ & $0 \cdot 50$ & $0 \cdot 18$ & $0 \cdot 10$ & $0 \cdot 02$ & 0 \\
\hline Nitrate & & $2 \cdot 30$ & 1.08 & 0.35 & $0 \cdot 21$ & 0.05 & 0 \\
\hline Dinitrogen & & $6 \cdot 60$ & 3.04 & 0.79 & 0.53 & $0 \cdot 20$ & 0 \\
\hline
\end{tabular}
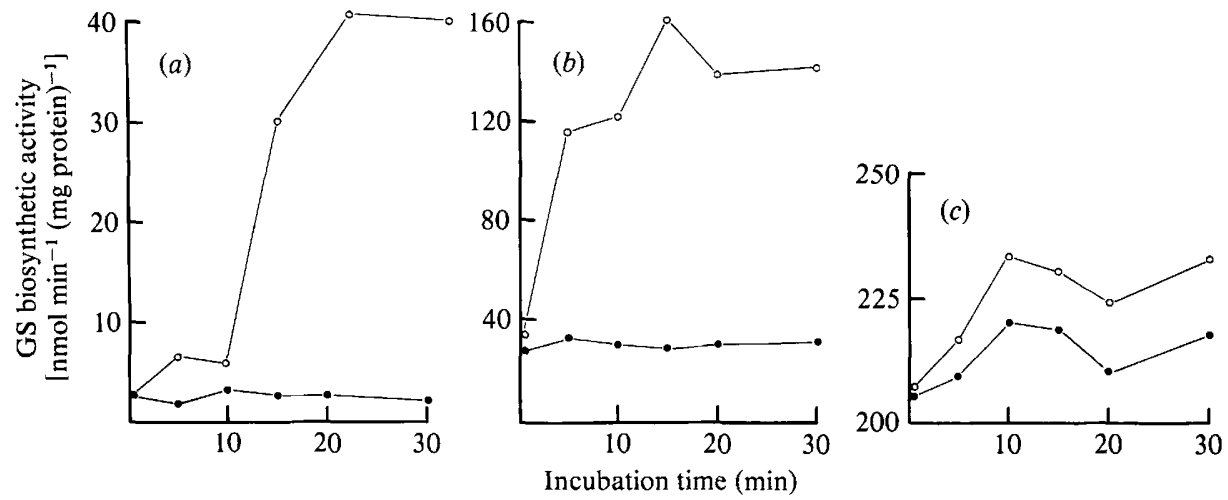

Fig. 4. Effect of SVP on the $\mathrm{Mg}^{2+}$-dependent biosynthetic activity of GS. Cells were grown in steadystate oxygen-limited chemostat culture. The enzyme was extracted, partially purified and assayed for activity in the presence $(O$; SVP-treated) and absence $(O$; control) of SVP. (a) Cells grown on ammonia-supplemented medium; $(b)$ cells grown on nitrate-supplemented medium; $(c)$ cells grown on dinitrogen-based medium.

In similar experiments it was observed that GS from M. capsulatus (Bath) showed absolute specificity for $\mathrm{Mg}^{2+}$ in the biosynthetic assay. Of all the divalent cations tested, only $\mathrm{Mn}^{2+}$ caused inhibition of $\mathrm{Mg}^{2+}$-dependent biosynthetic activity $\left(50 \%\right.$ inhibition with $2 \mathrm{~mm}-\mathrm{MnCl}_{2}$ present in the assay mixture).

When cell extracts from ammonia-, nitrate- or dinitrogen-grown cells harvested from steadystate cultures were assayed for $\mathrm{Mg}^{2+}$-dependent biosynthetic activity, values of 0,64 and 98 $\mathrm{nmol} \min ^{-1}$ (mg protein $)^{-1}$, respectively, were observed. However, when these extracts were assayed for $\gamma$-glutamyltransferase activity in the presence of $20 \mathrm{~mm}-\mathrm{Mg}^{2+}$ to inhibit nonbiosynthetic activity, none of the extracts showed any activity although they all contained GS at varying levels (Table 6). Furthermore, decreasing the $\mathrm{Mg}^{2+}$ concentration for each extract showed the same relative increase in transferase activity, indicating that GS in each extract was equally adenylylated [according to the formula devised by Stadtman et al. (1970)]. Since the measured biosynthetic activities for these extracts indicated a large variance in the state of adenylylation for the enzyme according to growth conditions, it was clear that the $\gamma$ glutamyltransferase assay could not be used reliably to determine the state of adenylylation in this organism.

\section{Demonstration of adenylylation of GS by SVP treatment}

In vitro deadenylylation of adenylylated enzyme by SVP has been described for a number of bacterial GS enzymes, including E. coli (Stadtman et al., 1970), A. vinelandii (Siedel \& Shelton, 1979), Pseudomonas aeruginosa (Janssen et al., 1980) and 'Streptomyces cattleya' (Streicher \& Tyler, 1981). In each case SVP cleaved off AMP groups from the adenylylated enzyme rendering it biosynthetically active. Partially purified GS preparations (after the Sepharose 4B step in 
purification) from $M$. capsulatus (Bath) grown in continuous culture on ammonia-, nitrate- and dinitrogen-based medium were each treated with SVP as described in Methods. Samples were taken from each incubation mixture at $5 \mathrm{~min}$ intervals and assayed for $\mathbf{M g}^{2+}$-dependent biosynthetic activity (Fig. 4). SVP treatment of GS from ammonia-grown cells resulted in the appearance of $\mathrm{Mg}^{2+}$-dependent biosynthetic activity, suggesting that the enzyme had been deadenylylated. Identical treatment of GS from nitrate-grown cells caused an increase in biosynthetic activity, indicating that the enzyme from these cells was initially partially adenylylated. Activity of GS from dinitrogen-grown cells was unaffected by SVP showing that the enzyme from $\mathrm{N}_{2}$-fixing cells was not adenylylated but was present in its fully biosynthetically active form. AMP cleaved off GS from ammonia-grown cells was identified by TLC, confirming that in $M$. capsulatus (Bath) glutamine synthetase activity is controlled not only by feedback inhibition of the end-products of glutamine metabolism but also by the system of adenylylation/deadenylylation which has been found in many other Gram-negative bacteria.

We wish to thank the Science Research Council for the award of a research studentship to J.C.M.

\section{REFERENCES}

Alef, K., Burkardt, H. J., Horstmann, H. J. \& ZUMFT, W. G. (1981). Molecular characterization of glutamine synthetase from the nitrogen-fixing phototrophic bacterium Rhodopseudomonas palustris. Zeitschrift für Naturforschung 36, 246-254.

Baginski, E. S., FoA, P. P. \& ZAK, B. (1967). Microdetermination of inorganic phosphate, phospholipids and total phosphate in biological materials. Clinical Chemistry 13, 326-330.

Bailey, M. L., Downs, J. \& Drozd, J. W. (1978). Nitrogen metabolism in Methylococcus NCIB 11083. Proceedings of the Society for General Microbiology 5, 65-66.

Bender, R. A., Janssen, K. A., Resnick, A. D., BlumenberG, M., FoOR, F. \& Magasanik, B. (1977). Biochemical parameters of glutamine synthetase from Klebsiella aerogenes. Journal of Bacteriology 129, 1001-1009.

DALTON, H. (1979). Utilization of inorganic nitrogen by microbial cells. In International Review of Biochemistry 21, pp. 227-266. Edited by J. R. Quayle. Baltimore: University Park Press.

Dalton, H. \& Whittenbury, R. (1976). The acetylene reduction technique as an assay for the nitrogenase activity in the methane oxidizing bacterium Methylococcus capsulatus strain Bath. Archives of Microbiology 109, 147-151.

Deuel, T. F. \& Stadtman, E. R. (1970). Some kinetic properties of Bacillus subtilis glutamine synthetase. Journal of Biological Chemistry 245, 5206-5213.

GABRIEL, O. (1971). Analytical disc gel electrophoresis. Methods in Enzymology 22, 565-578.

Ginsburg, A. \& StadtMan, E. R. (1973). Regulation of glutamine synthetase in Escherichia coli. In The Enzymes of Glutamine Metabolism, pp. 9-44. Edited by S. Prusiner \& E. R. Stadtman. New York: Academic Press.

Hubbard, J. S. \& Stadtman, E. R. (1967a). Regulation of glutamine synthetase. II. Patterns of feedback inhibition in microorganisms. Journal of Bacteriology 93, 1045-1055.

Hubbard, J. S. \& Stadtman, E. R. (1967b). Regula- tion of glutamine synthetase. VI. Interactions of inhibitors for Bacillus licheniformis glutamine synthetase. Journal of Bacteriology 94, 1016-1024.

Janssen, D. B., Hubb, J. M., Leenen, P. J. M. \& Van DER DRIFT, C. (1980). The enzymes of ammonia assimilation of Pseudomonas aeruginosa. Archives of Microbiology 124, 197-203.

Johansson, B. C. \& GEST, H. (1976). Inorganic nitrogen assimilation by the photosynthetic bacterium Rhodopseudomonas capsulata. Journal of Bacteriology 128, 683-688.

Johansson, B. C. \& Gest, H. (1977). Adenylylation/deadenylylation control of the glutamine synthetase of Rhodopseudomonas capsulata. European Journal of Biochemistry 81, 365-371.

Kingdon, H. S. \& StadtMan, E. R. (1967). Regulation of glutamine synthetase. X. Effect of growth conditions on the susceptibility of Escherichia coli glutamine synthetase to feedback inhibition. Journal of Bacteriology 94, 949-957.

Kleinschmidt, J. A. \& Kleiner, D. (1978). The glutamine synthetase from Azotobacter vinelandii: purification, characterization, regulation and localization. European Journal of Biochemistry 89, 51-60.

LAEMMLI, U. K. (1970). Cleavage of structural proteins during the assembly of the head of bacteriophage T4. Nature, London 227, 680-685.

O'FARrell, P. H. (1975). High resolution two-dimensional electrophoresis of proteins. Journal of Biological Chemistry 250, 4007-4021.

RANDERATH, K. \& RANDERATH, E. (1967). Thin-layer separation methods for nucleic acid derivations. Methods in Enzymology 12A, 323-346.

Sampaio, M. J. A. M., Rowell, P. \& Stewart, W. D. P. (1979). Purification and some properties of glutamine synthetase from the nitrogen-fixing Cyanobacteria Anabaena cylindrica and a Nostoc sp. Journal of General Microbiology 111, 181-191.

Shapiro, B. M. \& Stadtman, E. R. (1970). Glutamine synthetase (Escherichia coli). Methods in Enzymology 17A, 910-941.

Shishkina, V. N. \& Trotsenko, Y. A. (1979). 
Pathways of ammonia assimilation in obligate methane utilizers. FEMS Microbiology Letters 5, 187-191.

Siedel, J. \& Shelton, E. (1979). Purification and properties of Azotobacter vinelandii glutamine synthetase. Archives of Biochemistry and Biophysics 192, 214-224.

Stacey, G., Van Baalen, C. \& Tabita, F. R. (1979). Nitrogen and ammonia assimilation in the Cyanobacteria: regulation of glutamine synthetase. Archives of Biochemistry and Biophysics 194, 457-467.

Stadtman, E. R., Ginsburg, A., Ciardi, E., Yeh, S., HenNig, B. \& Shapiro, B. M. (1970). Multiple molecular forms of glutamine synthetase produced by enzyme catalysed adenylation and deadenylation reactions. Advances in Enzyme Regulation 8, 99-118.

Streicher, S. L. \& Tyler, B. (1981). Regulation of glutamine synthetase. Activity by adenylation in the Gram-positive bacterium Streptomyces cattleya. Proceedings of the National Academy of Sciences of the United States of America 78, 229-233.

Tempest, D. W., Meers, J. L. \& Brown, C. M. (1973). Glutamate synthase (GOGAT): a key enzyme in the assimilation of ammonia by prokaryotic organisms. In The Enzymes of Glutamine Metabolism, pp. 167182. Edited by S. Prusiner \& E. R. Stadtman. New York: Academic Press.
TYLER, B. (1978). Regulation of the assimilation of nitrogen compounds. Annual Review of Biochemistry 47, 1127-1162.

Wedler, F. C. \& Hoffman, F. M. (1974). Glutamine synthetase of Bacillus stearothermophilus. I. Purification and basic properties. Biochemistry 13, 32073214.

Wedler, F. C., Carfi, J. \& Ashour, A. E. (1976). Glutamine synthetase of Bacillus stearothermophilus. Regulation, site interactions, and functional information. Biochemistry 15, 1749-1755.

Whittendury, R., Phillips, K. C. \& Wilkinson, J. F. (1970). Enrichment, isolation and some properties of methane-utilizing bacteria. Journal of General Microbiology 61, 205-218.

Woolfolk, C. A. \& Stadtman, E. R. (1964). Cumulative feedback inhibition in the multiple and product regulation of glutamine synthetase in Escherichia coli. Biochemical and Biophysical Research Communications 17, 313-319.

Woolfolk, C. A., Shapiro, B. M. \& Stadtman, E. R. (1966). Regulation of glutamine synthetase. I. Purification and properties of glutamine synthetase from Escherichia coli. Archives of Biochemistry and Biophysics 116, 177-192. 